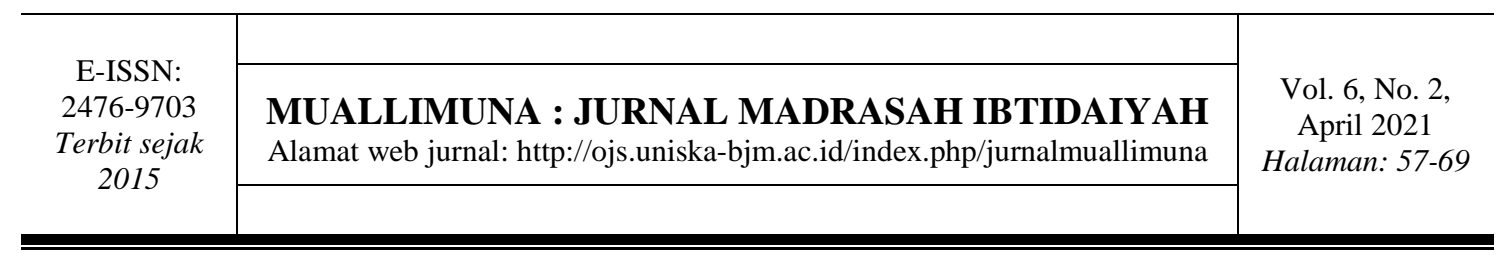

\title{
ANALISIS KELAYAKAN VIDEO PEMBELAJARAN IPS JENJANG MI/SD DI PLATFORM YOUTUBE PADA MATERI KERAGAMAN AGAMA DI INDONESIA
}

\author{
Waluyo Satrio Adji ${ }^{1}$, Muhammad Iqbal Ansari ${ }^{2}$, Abdul Bashith ${ }^{3}$, Melani Albar ${ }^{4}$ \\ ${ }^{13}$ Universitas Islam Negeri Maulana Malik Ibrahim Malang \\ ${ }^{2}$ Universitas Islam Kalimantan Muhammad Arsyad Al Banjari Banjarmasin \\ ${ }^{4}$ Universitas Islam Raden Rahmat Malang \\ 1'waluyo.satrio.adji@ uin-malang.ac.id, ${ }^{2}$ muhammadiqbalansari@ gmail.com, \\ 2abbash98@pips.uin-malang.ac.id ${ }^{4}$ ibnu.wagir@gmail.com
}

\begin{abstract}
Abstrak: Tujuan dari penelitian ini untuk menganalisis dan mendeskripsikan kelayakan video pembelajaran di platform youtube materi keragaman agama di Indonesia. Pendekatan kualitatif dengan studi dokumentasi digunakan dalam penelitian ini, secara khusus pengumpulan data sekunder dikumpulkan melalui platform yotuber dengan kata kunci "IPS keragaman Agama di Indonesia", kemudian video dianalisis berdasarkan Standar Kelayakan dari Badan Standar Nasional Pendidikan (BSNP) yaitu aspek isi dan penyajian, bahasa. Hasilnya peneliti menganalisis duabelas video pembelajaran IPS dari chanel yang berbeda, rata-rata pada aspek isi sebesar $67,5 \%$ berpredikat layak; bahasa sebesar $71,4 \%$ berpredikat layak; penyajian sebesar 73,3\% berpredikat layak; kegrafikan sebesar $71,5 \%$ berpredikat layak. Pada ke empat aspek kelayakan menandakan bahwa videp pembelajaran IPS layak untuk dijadikan rujukan dalam Pembelajaran.
\end{abstract}

Kata Kunci: Analisis kelayakan, Keragaman Agama, Platform Youtube, Video Pembelajaran IPS

\section{FEASIBILITY ANALYSIS OF MI/SD IPS LEARNING VIDEO IN YOUTUBE PLATFORM ON RELIGIOUS DIVERSITY MATERIALS IN INDONESIA}

\begin{abstract}
The purpose of this study is to analyze and describe the feasibility of learning videos on the YouTube platform on the diversity of religions in Indonesia. A qualitative approach with a documentary study is used in this research, in particular, secondary data was collected through the YouTuber platform with the keyword "IPS on Religious Diversity in Indonesia", then a video based on the Feasibility Standards from the National Education Standards Agency (BSNP), namely content and presentation aspects, language. The results of the researchers analyzed the social studies learning videos from different content, on average $67.5 \%$ of the content aspect was predicated; language of $71.4 \%$ has a decent predicate; presentation of $73.3 \%$ was categorized as feasible; $71.5 \%$ of the predicate is feasible. The four aspects of feasibility indicate that the social studies learning video is feasible to be used as a reference in learning.
\end{abstract}

Keywords: Feasibility analysis, Religious Diversity, Youtube Platform, Social Studies Learning Video 


\section{PENDAHULUAN}

Wabah virus corona yang tersebar di Indonesia berdampak pada berbagai sektor khususnya sektor pendidikan (Siahaan, 2020) (Widagdo et al., 2020), beragam persepsi atas dampak wabah virus corona dari stakeholder pendidikan berdasarkan pengalaman mengajar selama wabah berlangsung seperti keluhan atas sarana prasaran, akses internet, gaya belajar, serta evaluasi (Satrianingrum \& Prasetyo, 2020). Sebagai respon atas wabah covid 19 Kementrian Pendidikan dan Kebudayaan di bawah kordinasi pemerintah menerbitkan peraturan tanggal 24 maret tahun 2020 (Kementrian Pendidikan Dan Kebudayaan Republik Indonesia, 2020) sebagai upaya untuk mencegah masyarakat agar tidak terjangkit wabah virus corona. Dunia pendidikan mewujudkannya dengan pembatasan penyelenggaraan pendidikan di sekolah seperti ditutupnya sementara sekolah, mengganti pembelajaran tatap muka dengan pembelajaran jarak jauh dilaksanakan di sekolah, penggunaan media dalam pelaksanaan pembelajaran (Syah, 2020).

Penggunaan platform sebagai media pendukung dalam menjaga kualitas pembelajaran jarak jauh begitu penting(Hariani \& Wastuti, 2020). salah satunya pemanfaatan platform youtube(L. Sari, 2020) (Setiawan et al., 2021). Youtube pada laporan di jurnal Global Digital Insights jumlah pengguna youtube terbanyak pada tahun 2020 (Kemp, 2020) pada segi platform media sosial yang digunakan masih menempati posisi pertama dengan persentase $88 \%$ dibanding platform media sosial seperti instagram, twitter, facebook. Melihat favoritnya juga dapat diamati pada laporan tahun 2019(Kemp, 2019).

Persentase pengguna youtube yang tinggi sebenernya sudah dapat diprediksi jika jika dibreakdown ke bawah dari bentuk video sebagai medianya, video memiliki kriteria layak(Nur Latifah, Najib Hasan, 2015) dan respon yang sangat baik untuk dijadikan bahan pembelajaran di era pandemi covid 19(Batubara \& Batubara, 2020). Pada pemanfaatan platform youtube sebagai media pembelajaran dalam mengunggah video pembelajaran menyediakan kemudahan seperti syarat yang diminta terkait kualitas isi tidak ada, jadi pengguna yang memiliki akun youtube dapat mengunggah video apapun dengan syarat tidak mengandung konten negatif seperti konten bermuatan kekerasan, pornografi, sesuatu yang illegal atau melanggar hak cipta (L. Sari, 2020).

Permasalahan didapat jika melihat isi dari video pembelajaran yang telah diunggah di youtube, tidak adanya standar kelayakan video pembelajaran sebagai pendukung pembelajaran jarak jaruh menjadi permasalahan tersendiri. Padahal pada sejarah Pendidikan Indonesia dibentuknya Badan Standar Nasional Pendidikan (BSNP) adalah untuk menilai kelayakan buku. Hal tersebut pengejewantahan dari peraturan mendikbud No.2 tahun 2008 pasal 4 ayat 1 berbunyi "Buku teks pada jenjang pendidikan dasar dan menenah dinilai kelayakan pakainya terlebih dahulu oleh Badan Standar Nasional Pendidikan (BSNP) sebelum digunakan oleh pendidik atau peserta didik sebagai sumber belajar".

Pada undang-undang secara eksplisit tidak menyebutkan video pembelajaran tetapi secara substansi menyoroti kesalahan isi dan bahasa dalam sebuah sumber belajar. Jika mengamati kesalahan yang ada pada video unggahan dapat dipahami dari referensi yang menganalisis pada isi dan bahasa, pada program youtube Baim Paula kesalahan ejaan terjadi pada semisal ejaan bahasa dalam beribacara dan kesalahan kata-kata pada teks yang ada di video (Irmawati et al., 2020). Hasil observasi aspek isi pada video pembelajaran IPS terdapat beberapa catatan yang perlu diperhatikan seperti tidak adanya Kompetensi Inti, Kompetensi Dasar dalam isi video, dan materi yang terkesan 
plagiatisme dengan tidak menyebutkan daftar rujukan yang digunakan sebagai materi pembelajaran.

Guna meminimalisir kesalahan isi, bahasa, penyajian, dan kegrafikan dalam video pembelajaran maka diperlukan sebuah analisis isi, bahasa, penyajian, dan kegrafikan pada video pembelajaran. Kelayakan Isi pada sumber pembelajaran dalam perspektif Masnur Muslich harus memperhatikan materi dengan kompetensi yang ada pada kurikulum, ketepatan materi, dan materi penyerta yang mendukung. Sedangkan kelayakan bahasa harus mengacu kepada kriteria kebahasaan, baiknya bahasa berbanding lurus dengan penerima pesan karena pada bahasa terdapat semua pesan dan informasi (Muslich, 2010b).

Kajian analisis isi dan bahasa terkait video pembelajaran yang ada pada youtube sudah pernah diteliti dengan objek saluran video khusus menyediakan konten pembelajaran seperti Labedu dan Ruang Guru (Cahyana \& Kosasih, 2020), jika ditelaah hanya mengkaji dua saluran pembelajaran sementara video oleh pengunggah lain dengan materi yang sama tidak dikaji. Kajian analisis pada video pembelajaran di youtube juga diteliti dengan pengumpulan data melalui keyword sehingga data yang dihasilkan semateri(Suprapto \& Suprapto, 2021), pada ukuran kelayakan dilakukan secara mandiri .

Pada isi materi IPS di MI/SD tema keragaman penting untuk dipahami secara baik, karena pemahaman yang tidak baik tentang bagaimana hidup dalam keragaman agama dapat melahirkan konflik horizontal atas perbedaan identias agama (Kushendrawati, 2012)(Febriyandi.YS, 2019), seperti konflik di Situbondo, Poso, Ambon, Ketapang, dsb sederetan konflik yang menimbulkan korban jiwa tersebut dapat dikatakan bahwa agama adalah paling sensitif pada konteks Indonesia (Kushendrawati, 2012). Untuk itu materi keragaman agama perlu ditanamkan sejak di dini karena masa tersebut kepekaan anak besar dalam menerima pengaruh dari sekitar, jika dipengaruhi dari pemahaman keragaman agama secara baik dapat dipastikan perilaku anak dapat toleran, adil, dan menghargai perbedaan agama dalam hidup bermasyarakat(Agung, 2017).

Atas dasar pemaparan di atas, peneliti ttarik melakukan penelitian analisis kelayakan Isi dan Bahasa di video pembelajaran di platform youtube. Penelitian ini di harapkan dapat dijadikan referensi bagi guru-guru IPS sehingga dapat lebih selektif dalam memilih dan menilai video pembelajaran IPS yang baik dan benar untuk dijadikan sumber pembelajaran IPS.

\section{METODE}

Pendekatan kualitatif termasuk dalam penelitian ini, sedangkan metode penelitian menggunakan kajian pustaka yang di dalamnya peneliti mengumpulkan data dari pustaka dan menganalisis data dalam bentuk catatan, transkip, buku, surat kabar, majalah, prasasti, notulen rapat, lengger, agenda, dan sebagainya (Arikunto, 2012).

Sumber data dalam penelitian termasuk jenis data sekunder karena tidak langsung ke objek yang sedang diteliti(Sugiyono, 2012) tetapi berupa video pembelajaran bertema keragaman agama di Indonesia yang diunggah oleh pengguna di platform www.youtube.com. Kriteria data dalam pemilihan video pembelajaran diambil semua dengan syarat sesuai dengan kata kunci yaitu IPS Keragaman Agama di Indonesia, kemudian peneliti mensortir data disesuaikan seperti jumlah yang pernah melihat video, penyuka, dan lalu lintas komentar yang ada pada setiap video. 
Teknik pengumpulan data dilakukan dengan pedoman sesuai dengan standar BSNP (Badan Standar Nasional Pendidikan dan Pusat Perbukuan, 2014) yang dikembangkan ke beberapa indikator, meskipun penilaian kelayakan tertuang pada buku teks tetapi tidak menutup kemungkinan untuk dikaji pada objek video pembelajaran karena dijadikan sumber pembelajaran(Cahyana \& Kosasih, 2020). Penentuan kelayakan atas video dilakukan oleh tiga dosen pendidikan dengan kualifikasi 2 dosen jurusan Ilmu Pengetahuan Sosial dari Universitas Islam Negeri Maulana Malik Ibrahim Malang, 1 dosen bidang agama dari Universitas Islam Kalimantan Syekh Arsyad Al Banjari, dan 1 dosen pembelajaran bahasa arab dari Universitas Islam Raden Rahmat Malang.

Tabel Indikator isi, penyajian, bahasa, dan kegrafikan adalah pengembangan aspek kelayakan diterbitkan oleh BSNP. Berikut merupakan instrumen penelitian analisis isi, bahasa, penyajian, dan kegrafikan yang telah dikembangkan ke beberapa indikator:

Tabel 3. Kelayakan Isi

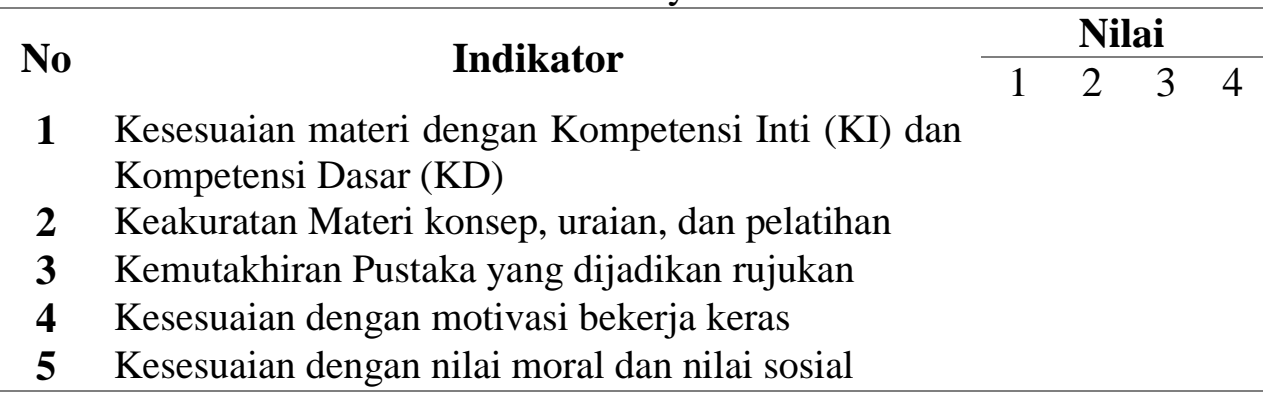

Sumber : (Badan Standar Nasional Pendidikan dan Pusat Perbukuan, 2014)

Tabel 4. Kelayakan Penyajian

\begin{tabular}{lllll}
\hline \multirow{2}{*}{ No } & \multicolumn{1}{c}{ Indikator } & \multicolumn{3}{c}{ Nilai } \\
\cline { 3 - 4 } $\mathbf{1}$ & $\begin{array}{l}\text { Penyajian konsep disajikan secara runtun mulai } \\
\text { dari yang mudah ke sukar }\end{array}$ & & & \\
& & & \\
$\mathbf{2}$ & $\begin{array}{l}\text { Terdapat contoh-contoh soal yang dapat } \\
\text { membantu menguatkan pemahaman }\end{array}$ \\
$\mathbf{3}$ & $\begin{array}{l}\text { Kesesuaian Informasi dengan kebutuhan peserta } \\
\text { didik }\end{array}$ \\
$\mathbf{4}$ & $\begin{array}{l}\text { Kejelasan suara dalam penyampaian } \\
\text { Kesuaian Keruntutan (pendahuluan-isi-evaluasi) } \\
\text { penyajian }\end{array}$ \\
\hline Sumber : (Badan Standar Nasional Pendidikan dan Pusat Perbukuan, 2014)
\end{tabular}

Tabel 5. Kelayakan Bahasa

\begin{tabular}{|c|c|c|c|c|c|c|}
\hline \multirow[b]{2}{*}{ No } & \multirow{2}{*}{\multicolumn{2}{|c|}{ Indikator }} & \multicolumn{4}{|c|}{ Nilai } \\
\hline & & & & 2 & 3 & 4 \\
\hline 1 & $\begin{array}{l}\text { Kesesuaian kosa } \\
\text { peserta didik }\end{array}$ & kata dengan perkembangan & & & & \\
\hline 2 & Kesuaian kalimat y & ang dapat dipahami & & & & \\
\hline 3 & Dialogis dan interal & & & & & \\
\hline 4 & Konsisten menggun & lakan istilah yang sama & & & & \\
\hline
\end{tabular}


$5 \quad$ Penggunaan bahasa yang baku

Sumber : (Badan Standar Nasional Pendidikan dan Pusat Perbukuan, 2014)

Tabel 6. Kelayakan Grafika

\begin{tabular}{lllll}
\hline \multirow{2}{*}{ No } & \multicolumn{1}{c}{ Indikator } & \multicolumn{3}{c}{ Nilai } \\
\cline { 3 - 4 } $\mathbf{1}$ & \multicolumn{1}{c}{ Kesuaian gambar dengan materi } & 2 & 3 & 4 \\
$\mathbf{2}$ & $\begin{array}{l}\text { Kesesuaian ukuran gambar depan dengan rasio } \\
\text { video }\end{array}$ & & \\
& & & \\
$\mathbf{3}$ & Kekontrasan gambar depan dengan latar belakang & & \\
$\mathbf{4}$ & Kekontrasan gambar isi dengan latar belakang & \\
$\mathbf{5}$ & Resolusi video yang jelas & \\
\hline
\end{tabular}

Sumber : (Badan Standar Nasional Pendidikan dan Pusat Perbukuan, 2014)

Penentuan skor dalam pengisian setiap standar dari BSNP meliputi isi dan bahasa menggunakan skala likert.

Tabel 1.Indikator Penilaian

\begin{tabular}{cc}
\hline Indikator & Nilai \\
\hline Sangat Baik & 4 \\
Baik & 3 \\
Cukup Baik & 2 \\
Tidak Baik & 1 \\
\hline
\end{tabular}

Dari jumlah skor tersebut kemudia dijadikan persentase dengan rumus : skor peroleh/ skor maksimal x 100. Kriteria dari persentase kemudian ditafsirkan sesuai dengan kriteri berikut:

Tabel 2. Kriteria Persentase

\begin{tabular}{cc}
\hline Persentase $(\%)$ & Kriteria \\
\hline $\mathbf{0 - 2 0}$ & Sangat Tidak Layak \\
$\mathbf{2 1 - 4 0}$ & Kurang Layak \\
$\mathbf{4 1 - 6 0}$ & Cukup Layak \\
$\mathbf{6 1 - 8 0}$ & Layak \\
$\mathbf{8 1 - 1 0 0}$ & Sangat Layak \\
\hline
\end{tabular}

Pada kriteria dinyatakan sangat layak jika skor persentase di bawah $100 \%$, hal yang sama dengan interval 20 dengan turun pada kriteria layak di bawah $80 \%$, kriteria cukup layak di bawah $60 \%$, Kriteria kurang layak di bawah $40 \%$, dan kriteria sangat tidak layak di bawah $20 \%$.

\section{HASIL DAN PEMBAHASAN \\ Hasil}

Data yang dihimpun dengan metode dokumentasi maka di dapat sebanyak 12 video dengan judul keberagaman agama di Indonesia, video tersebut disajikan untuk kelas 4 jenjang MI/SD. Data diambil pada bulan februari tahun 2021. Lebih rinci terkait video dari youtube.com ditampilakn dalam tabel berikut: 
Tabel 7. Video Pembelajaran dari Youtube Materi Keragaman Agama di Indonesia

\begin{tabular}{|c|c|c|c|c|c|c|}
\hline No & Akun & Judul & Penonton & Komentar & Suka & $\begin{array}{l}\text { Waktu } \\
\text { Unggah }\end{array}$ \\
\hline 1 & Pintar Belajar & $\begin{array}{l}\text { Materi Ips Tema } 1 \\
\text { Kelas } 4 \text { Sd } \\
\text { Keragaman Agama } \\
\text { Di Indonesia }\end{array}$ & 7200 & 36 & 123 & $\begin{array}{l}26 \text { Juli } \\
2020\end{array}$ \\
\hline 2 & $\begin{array}{l}\text { Sdksantoyusup2 } \\
\text { Kelas4 }\end{array}$ & $\begin{array}{l}\text { Materi IPS Tema } 1 . \\
\text { Keragaman Agama } \\
\text { Di Indonesia }\end{array}$ & 5800 & 0 & 112 & $\begin{array}{l}15 \text { Juli } \\
2020\end{array}$ \\
\hline 3 & Pustaka rama & $\begin{array}{l}\text { Keragaman Agama } \\
\text { di Indonesia }\end{array}$ & 52000 & 1100 & 309 & $\begin{array}{l}6 \text { Februari } \\
2021\end{array}$ \\
\hline 4 & N3house & $\begin{array}{l}\text { Keragaman Agama } \\
\text { di Indonesia }\end{array}$ & 4100 & 55 & 266 & $\begin{array}{l}22 \text { Januari } \\
2021\end{array}$ \\
\hline 5 & Cerita Inspirasi & $\begin{array}{l}\text { Keberagaman } \\
\text { Agama Di Indonesia } \\
\text { (IPS) }\end{array}$ & 229 & 0 & 12 & $\begin{array}{l}31 \text { Agustus } \\
2020\end{array}$ \\
\hline 6 & $\begin{array}{l}\text { Carroline } \\
\text { Elisabet }\end{array}$ & $\begin{array}{l}\text { Keragaman Agama } \\
\text { di Indonesia || } \\
\text { Tematik Muatan IPS } \\
\text { | Kelas } 4 \text { semester } 1\end{array}$ & 430 & 4 & 33 & $\begin{array}{c}23 \mathrm{Juli} \\
2020\end{array}$ \\
\hline 7 & Fico Polii & $\begin{array}{l}\text { Materi IPS Kelas } 4 \\
\text { Keragaman Agama } \\
\text { di Indonesia }\end{array}$ & 389 & 1 & 20 & $\begin{array}{l}29 \mathrm{Juli} \\
2020\end{array}$ \\
\hline 8 & $\begin{array}{l}\text { Johanse } \\
\text { Leonardo }\end{array}$ & $\begin{array}{c}\text { Keberagaman } \\
\text { Agama di } \\
\text { Indonesia... }\end{array}$ & 43000 & 33 & 406 & $\begin{array}{c}21 \\
\text { November } \\
2017\end{array}$ \\
\hline 9 & Betti Indriyani & $\begin{array}{l}\text { Video Pembelajarn } \\
\text { "Keragaman Agama } \\
\text { di Indonesia" }\end{array}$ & 304 & 0 & 9 & $\begin{array}{l}15 \mathrm{Mei} \\
2020\end{array}$ \\
\hline 10 & $\begin{array}{l}\text { SD Islam Al } \\
\text { Huda } 2 \text { Kediri }\end{array}$ & $\begin{array}{c}\text { IPS kelas } 4 \\
\text { (Keragaman Agama } \\
\text { di Indoensia) }\end{array}$ & 188 & 5 & 8 & $\begin{array}{l}22 \text { Juli } \\
2020\end{array}$ \\
\hline 11 & Guruku & $\begin{array}{l}\text { Media Pembelajaran } \\
\text { IPS SD Kelas 4- } \\
\text { Kebergaman Agama } \\
\text { Di Indonesia }\end{array}$ & 71 & 0 & 8 & $\begin{array}{l}1 \text { Agustis } \\
2020\end{array}$ \\
\hline 12 & $\begin{array}{c}\text { MI } \\
\text { Muhammadyah } \\
\text { Juwar }\end{array}$ & $\begin{array}{l}\text { IPS- Keberagaman } \\
\text { Agama di Indonesia }\end{array}$ & 58 & 0 & 2 & $\begin{array}{l}11 \text { Agustis } \\
2020\end{array}$ \\
\hline
\end{tabular}

Pada tabel di atas dapat diamati bahwa akun pengunggah video pembelajaran bertema Keragaman agama di Indonesia terdiri dari 9 akun pribadi dan 3 akun lembaga sekolah. Pada paltform youtube, akun siapapun dapat mengunggah video dengan syarat memenuhi aturan seperti tidak mengunggah sesuatu yang melanggar norma publik seperti mengunggah video pembunuhan, hinaan, dan pornografi. Hal ini menjadikan youtube dapat dijadikan sumber belajar bagi generasi milenial(Setiadi et al., 2019)

Kolom judul tampak tidak konsisten dalam penggunaan Ejaan yang benar, mulai dari besar kecil sampai penggunaan tanda baca yang tidak lazim. Seperti pada akun Carroline Elisabet terlihat penggunaan // untuk memisahkan judul, hal tersebut tidak lazim digunakan pada ejaan yang disempurnakan. Akan tetapi hal tersebut tidak dapat 
dihindari karena filter dari platform tidak sampai pada ejaan bahasa (Setiadi et al., 2019) atau PUEBI (Pedoman Umum Ejaan Bahasa Indonesia) (Badan Bahasa Kemendikbud, 2016). Pada media massa daring detik.com, kesalahan ejaan juga tidak dapat terhindarkan seperti kesalahan pada huruf miring, tanda baca, huruf miring, dan penggunaan angka-angka(Winata, 2019).

Selanjutnya kolom 3 yaitu jumlah penonton, jumlah terbanyak dimiliki oleh akun pustaka rama dengan jumlah penonton 52000 sedangkan paling sedikit diraih oleh akun MI Muhammadiyah Juwar dengan jumlah penonton 58. Jumlah penonton banyak dan sedikit tidak tergantung pada kreativitas dalam pembuatan video, kata kunci video, judul yang ada pada video.(Aprilia, n.d.)

Pada kolom keaktifan komentar paling banyak didapat oleh akun pustaka rama dengan jumlah 309 komentar, sedangkan mayoritas akun lain dibawah 100 Komentar, juga ada yang tidak ada komentar karena memang sengaja mematikan kolom komentar, sehingga akun penonton tidak dapat memberikan pesan atas video yang telah diunggah. Guna menaikkan lalu lintas komentar dan penyuka pada video di platform youtube, para pengunggah dituntut untuk kreatif dalam membuat konten isi pada youtube(Aprilia, n.d.)

Kolom berikutnya adalah penyuka video pembelajaran hal tersebut dapat dilihat dari paling banyak yaitu akun pustaka rama dengan jumlah penyuka mencapai 1100 dan paling sedikit bahkan tidak ada penyuka adalah akun MI Muhammadiyah Juwar dengan 2 penyuka, penyuka video dapat ditingkatkan jika konten di video kreatif (Aprilia, n.d.). Kolom terakhir pengunggah paling lama adalah akun Betty Indrayani dengan waktu unggah 15 Mei 2020 sedangkan paling terbaru adalah dari akun pustaka rama dengan waktu unggah 6 Februari 2021.

\section{Pembahasan}

Sesuai dengan Standar Badan Standar Nasional Pendidikan memberikan kriteria kelayakan suatu materi dalam dunia pendidikan yaitu ada kelayakan isi, penyajian, bahasa, dan grafik. Dalam penelitian ini menggunakan 4 aspek yaitu aspek isi, penyajian, dan grafika dalam menganalisis. Analisis dengan acuan dari BSNP pada 12 video diperoleh hasil persentase sebagai berikut:

Tabel 8. Analisis Kelayakan Video Pembelajaran IPS Materi

Keragaman Agama di Indonesia

\begin{tabular}{ccccccc}
\hline Akun & \multicolumn{5}{c}{ Analisis } \\
\cline { 2 - 7 } & Isi & Bahasa & Penyajian & Grafika & Rata-rata & Kriteria \\
Pintar Belajar & 75 & $(\%)$ & $(\%)$ & $(\%)$ & 78,75 & Layak \\
Sdksantoyusup2 & 74 & 80 & 80 & 80 & 75,75 & Layak \\
$\quad$ Kelas4 & & & 84 & 70 & & \\
Pustaka rama & 76 & 80 & 80 & 80 & 79 & Layak \\
$\quad$ N3house & 80 & 80 & 82 & 78 & 80 & Layak \\
Cerita Inspirasi & 60 & 62 & 68 & 64 & 63,5 & Layak \\
Carroline & 80 & 82 & 80 & 78 & 80 & Layak \\
$\quad$ Elisabet & & & & & & \\
Fico Polii & 62 & 60 & 60 & 68 & 61,5 & Layak \\
Johanse & 58 & 60 & 56 & 60 & 59,5 & Cukup Layak \\
Leonardo & & & & & & \\
Betti Indriyani & 70 & 68 & 74 & 74 & 71,5 & Layak \\
SD Islam Al & 58 & 76 & 70 & 74 & 69,5 & Layak \\
\hline
\end{tabular}




\begin{tabular}{ccccccc}
\hline $\begin{array}{c}\text { Huda 2 Kediri } \\
\text { Guruku }\end{array}$ & 60 & 78 & 70 & 68 & 69 & Layak \\
MI & 58 & 60 & 72 & 64 & 63,5 & Layak \\
$\begin{array}{c}\text { Muhammadyah } \\
\text { Juwar }\end{array}$ & & & & & & \\
$\begin{array}{c}\text { Rata-rata setiap } \\
\text { Aspek }\end{array}$ & 67,5 & 71,4 & 73,3 & 71,5 & & \\
\hline
\end{tabular}

\section{Kelayakan Isi}

Analisis data di atas diperoleh bahwa pada aspek isi persentase tertinggi diperoleh oleh video dari akun pustaka rama dengan skor $76 \%$. Sedangkan terendah dari aspek isi diperoleh oleh akun Linda Kristiana, SD Islam Al Huda Kediri, dan Johanes Leonardo dengan persentase $58 \%$, sedangkan rata-rata isi dari 12 video yang diunggah berkisar di persentase $67,5 \%$ dengan kriteria layak.

- Sedangkan kelayakan bahasa harus mengacu kepada kriteria kebahasaan, baiknya bahasa berbanding lurus dengan penerima pesan karena pada bahasa terdapat semua pesan dan informasi

Pada tabel keseuaian isi semua video mengacu pada Kompetensi Dasar yang terdapat pada kurikulum IPS di MI/SD kurikulum 2013 revisi, hanya saja tidak dicantumkan pada awal video sebelum masuk ke isi padahal Kompetensi Dasar adalah tujuan dari video pembelajaran IPS, padahal dalam kriteria pemilihan media pembelajaran wajib adanya tujuan yang jelas, dalam artikel yang diteliti Mahnun bahwa tujuan pembelajaran menjadi pertimbangan nomor dua sebagai pertimbangan pemilihan media pembelajaran (Mahnun, 2012). Hal ini selaras dengan pertimbangan muatan materi disesuaikan dengan kompetensi yang ada pada kurikulum (Muslich, 2010a). Terdapat catatan pada aspek ini yaitu tidak adanya uraian dari indikator pencapaian kompetensi dari kategori IPK pendukung, kunci, dan pengayaan tingkatan High Order Thinking Skill atau HOTS, padahal guru dituntut untuk menambah IPK ke level HOTS

Pada indikator keakuratan materi di sini materi yang disajikan pada video pembelajaran pada aspek konsep dari semua video sudah sesuai materi konsep IPS terlihat dari sub judul semua sepakai membagi agama menjadi 6 yaitu Islam, Katolik, Kristen, Buddha, Hindu, dan Kong $\mathrm{Hu} \mathrm{Cu}$. Sejalan dengan pernyataan muslich yaitu ketepatan materi, dan materi penyerta yang mendukung wajib ada pada sumber pembelajaran. Selanjutnya dari konsep agama diuraikan ke sub judul, pada aspek pelatihan di akhir sesi hanya di video pada akun carroline yang memberikan bentuk feedback berupa tugas di akhir video, padahal dalam langkah-langkah pemilihan media pembelajaran yang baik salah satunya adalah adanya latihan atas apa yang sudah dipelajari

Kemutakhiran Pustaka merujuk pada terbitan pustaka 2 tahun sebelum video diterbitkan dapat dinyatakan tidak ada, mayoritas akun yang ada tidak mencantumkan daftar pustaka atau sember materi, berasal dari mana materi tersebut dicantumkan. Secara kaidah sebuah karya adalah wajib mencantumkan pustaka rujukan sebagai pertanggungjawaban atas kutipan yang digunakan dan sebagai kebaruan materi ajar.

Indikasi motivasi terdapat di video yang menampilkan suara atau sosok guru atau mentor, di dalamnya terdapat sebuah yel-yel penyemangat bagi siswa untuk belajar, hal tersebut. Seperti dalam video yang diunggah akun MI Muhammadiyah Juwar, dengan kutipan "selamat pagi semoga tetap sehat dan tetap semangat". Tidak hanya di awal pemberian motivasi pada video yang ada, tetapi juga terdapat pada pertengahan dan akhir sesi dengan kata pesan positif seperti tetap semanagat untuk 
belajar, dapat dikatakan Semua akun ada indikasi penyemangat kecuali akun Johannes Leonardo karena tidak ada latar suara dan teks penyemangat jadi langsung ke materi pembelajaran.

Nilai moral dan sosial pada 12 video di akhir sesi dicantumkan seperti pesan untuk tetap menjaga persatua, dengan menanamkan pemahaman bahwa berbeda bukan untuk bercerai berai tetapi dapat menjadi kekuatan untuk bersama. Pada pesan terkait nilai moran dan sosial dapat dikatan bahwa ada di 11 video pembelajaran kecuali akun Fico Polli dan Johannes Leonardo, sampai akhir sesi tidak ada sesi pesan moral dan sosial dari materi yang telah disampaikan.

\section{Kelayakan Bahasa}

Pada aspek bahasa pada video, persentase paling banyak di dapat oleh akun pintar belajar, pustaka rama, n3house dengan $80 \%$, paling sedikit didapat oleh akun Fico Polli, MI Muhammadiyah Juwar dan Johannes Leonardo dengan 60\% sedangkan rata-rata isi dari 12 video yang diunggah berkisar di persentase 67,5\% dengan kriteria layak. Indikasi kesesuaian kosa kata dengan perkembangan peserta didik didapat dalam semua video. Hal ini selaras dengan kesesuaian materi dengan Kompetensi Dasar yang ada pada kurikulum. Terlihat dari bahasa dalam teks yang ditampilkan dalam video, kosa kata atau istilah asing tidak dipakai pada isi materi, hal ini penting untuk diperhatikan karena dalam pemilihan aspek pertimbangan siswa menempati posisi pertama(Mahnun, 2012).

Pada penulisan kalimat yang terdiri minimal terdiri dari Subjek, Predikat, dan Objek. Pada penjelasannya memberikan susunan SPOK, seperti pada video dari akun Fico Polli, menyatakan pada videonya "Indonesia Memiliki Banyak Keragaman", "Islam Mempunyai Kitab Suci bernama Al-Qur'an", dua kalimat tersebut sudah sah untuk memenuhi unsur pembentuk kalimat yaitu Indonesia sebagai Subjek, dan Memiliki sebagai Predikat (Badan Bahasa Kemendikbud, 2016).

Video pembelajaran IPS yang dialogis dan interaktif terdapat pada semua video, secara bahasa menggunakan kalimat yang memberikan pertanyaan, "halo apa kabar?, bagaimana kabarnya hari ini?", "bagaimana kawan-kawan sudah paham?". Istilah yang digunakan dalam video konsisten digunakan, dalam video pembelajaran istilah kitab suci semisal agama Islam konsisten disebut Al-Qur'an, begitu juga dengan kitab yang lain seperti Injil, Weda, dan Taurat. Selain itu penyebutan tempat ibadah, secara konsisten juga sama.

Pada penggunaan bahasa baku, pada video sulit menghindari bahasa tidak baku terutama pengucapan, semisal penyebutan istilah masjid, dalam ucapan disebutkan mesjid. Hal tersebu juga sama pada penulisan yang ada pada video pembelajaran, semisal di awal kalimat, memakai kata "di", dan "dalam", masih menjadi kesalahan yang dilakukan di beberapa video pembelajaran. Kesalahan dalam menulis kata dan kalimat tidak dapat dihindari dalam setiap unggahan di platform yang tidak ada filter bahasa (Irmawati et al., 2020).

\section{Kelayakan Penyajian}

Pada aspek penyajian video persentase paling banyak di dapat oleh akun Sdksantoyusup2 Kelas4 dengan $84 \%$. Sedangkan paling sedikit didapat oleh akun Johannes Leonardo dengan $56 \%$, sedangkan rata-rata isi dari 12 video yang diunggah berkisar di persentase $73,3 \%$ dengan kriteria layak. Pada runtun mulai dari mudah sampai tersulit semua video memuat prinsip penjelasan dari yang mudah yaitu 
pembagian awal dari keragaman agama di Indonesia kemudian di dalam penjelasan dirinci pada setiap agama dijelaskan satu persatu, di sini poin 4 didapat pada semua video pembelajaran IPS.

Indikasi pada pemberian contoh berupa simbol dan gambar didapat pada semua video, model penjelasan setiap agama dicantumkan berupa simbol dan gambar, semisal pada video dari pustaka rama, penjelasan agama Islam memberikan simbol bulan sabit, gambar masjid dan simbol salib sebagai penciri identitas dari agama yang Kristen(L. M. Sari, 2018). Hal yang sama dengan video lain dengan penjelasan agama yang berbeda, perbedaan nilai didapat karena ada sedikit yang tidak memberikan contoh nyata dalam kehidupan sehari-hari.

Kesuaian dengan kebutuhan peserta didik dapat dilihat dari jenis media yang digunakan yaitu video pembelajaran dari platform youtube yang merujuk kepada kompetensi dasar yaitu kebutuhan kompetensi siswa yang wajib dikuasai, selain itu dapat diketahui dari judul yang digunakan kata kunci yaitu "IPS;Keragaman Agama;Kelas IV'SD”. Pada indikator kejelasan suara 11 video memberikan latar suara sebagai penjelas kecuali Johannes Leonardo karena hanya memberikan musik di latar suara video. Pada keruntutan video pembelajaran 10 video memberikan pendahuluan sebelum masuk ke inti kecuali akun Fico Polli dan Johannes Leonardo. Perbedaan terdapat pada evaluasi hanya akun carroline yang memberikan evaluasi dalam bentuk tugas.

\section{Kelayakan Kegrafikan}

Pada aspek kegrafikan pada video, persentase paling banyak di dapat oleh akun pintar belajar, pustaka rama dengan $80 \%$. Sedangkan paling sedikit didapat oleh akun Johannes Leonardo dengan $60 \%$. Rata-rata pada aspek kegrafikan pada 71,5\% merujuk pada kriteria termasuk layak. Indikasi kegrafikan pada kesesuaian gambar denga materi setiap video pada gambar di depan pada semua video sudah merepresntasikan isi dari materi yang ada. Terdapat judul dan gambar, pada teknisnya sebelum mengunggah video di youtube ada pilihan untuk menggunakan cover yang berasal dari bagian video yang dijadikan gambar depan(Setiawan et al., 2021). Tidak hanya pilihan gambar yang sudah disediakan tetapi pengguna dapat mengunggah gambar depan jika dirasa kurang dapat mewakili isi video dengan cover yang ditampilkan, pada aspek ini poin dari video pada posisi 4 poin.

Indikasi pada rasio video pembelajaran yang diunggah pada semua video memili rasio standar, rasio standar pada unggahan video di youtube adalah 16:9 pada semua video rasio yang digunakan ada yang dari power point, umumnya dari power point sudah memiliki rasio dengan standar 16:9. Jadi saat diunggah gambar tidak terpotong, semisal video memiliki rasio vertikal 9:16 maka gambar akan terpotong karena berfokus di tengah. Mulai dari awal pengunggahan video, langkah demi langkah pengunggah video akan diarahkan pada menu rasio yang akan digunakan.

Kekontrasan atau komplementer adalah warna yang berseberangan atau berlawanan dengan warna lain, contoh warna kontras adalah merah dengan hijau, kuning dengan ungu dan biru dengan jingga(Warna - Wikipedia Bahasa Indonesia, Ensiklopedia Bebas, n.d.). Pada semua video tidak ada warna kontras yang mengakibatkan teks tidak dapat terbaca. Hal yang sama juga pada kekontrasan gambar isi dengan latar belakang tidak terdeteksi adanya kekontrasan.

Pada resolusi yang diunggah di platform youtube beresolusi 144p, 240p, 460, 480p, 720p, 1080p. Semakin tinggi resolusi pada video, semakin jelas kualitas video. 
Penonton memiliki pilihan untuk menentukan kualitas video yang akan ditonton, tidak jarang kuatnya sinyal dari sistem secara otomatis menentukan kualitas video. Pada video pembelajaran IPS dari 12 video tersebut resolusi paling tinggi pada akun n3house dengan 1080p, sedangkan pada 11 video lainnya berkisar 720p. Dapat dikatakan kualitas video pembelajaran termasuk tinggi.

\section{PENUTUP}

Analisis kelayakan menggunakan acuan dari Badan Standar Nasional Pendidikan yang terdiri dari empat aspek yaitu isi, penyajian, bahasa, dan kegrafikan. Hasil dari analisis diperoleh 11 video berpredikat layak dan 1 video berpredikat cukup layak. Masing-masing aspek memiliki rata-rata yaitu aspek isi sebesar 67,5\% berpredikat layak; bahasa sebesar $71,4 \%$ berpredikat layak; penyajian sebesar $73,3 \%$ berpredikat layak; kegrafikan sebesar 71,5\% berpredikat layak.

\section{DAFTAR PUSTAKA}

Agung, D. A. G. (2017). Keragaman Keberagaman (Sebuah Kodrati Kehidupan Berbangsa dan Bernegara Berdasarkan Pancasila). Sejarah Dan Budaya: Jurnal Sejarah, Budaya, Dan Pengajarannya, 11(2), 151-159. https://doi.org/10.17977/um020v11i22017p151

Aprilia, P. (n.d.). 9 Cara Menambah Viewer YouTube Paling Ampuh 2020. Https://www.niagahoster.co.id. Retrieved April 5, 2021, from https://www.niagahoster.co.id/blog/cara-menambah-viewer-youtube/?amp

Arikunto, S. (2012). Prosedur Penelitian: Suatu Pendekatan Praktik (Edisi Revisi). In Rineka Cipta.

Badan Bahasa Kemendikbud. (2016). Pedoman Umum Ejaan Bahasa Indonesia. In Pedoman Umum Ejaan Bahasa Indonesi (Vol. 4). http://badanbahasa.kemdikbud.go.id/lamanbahasa/sites/default/files/PUEBI.pdf\#pa ge $=8 \&$ zoom $=$ auto, $-195,422$

Badan Standar Nasional Pendidikan dan Pusat Perbukuan. (2014). Instrumen Penilaian Tahap I dan Tahap II Buku Teks Pelajaran Pendidikan Dasar Dan Menengah. http://bsnp-indonesia.org/?p=1340

Batubara, H. H., \& Batubara, D. S. (2020). Penggunaan Video Tutorial Untuk Mendukung Pembelajaran Daring di Masa Pandemi Virus Corona. Muallimuna: $\begin{array}{llll}\text { Jurnal Madrasah } & \text { Ibtidaiyah, }\end{array}$ https://doi.org/10.31602/muallimuna.v5i2.2950

Cahyana, A. D., \& Kosasih, E. (2020). Analisis Kelayakan Video Pembelajaran untuk Jenjang SD di Saluran Youtube Ruangguru dan Labedu Channel. PEDADIDAKTIKA: Jurnal Ilmiah Pendidikan Guru Sekolah Dasar, 7(4), 132144. https://doi.org/10.17509/md.v16i1.26363

Febriyandi.YS, F. (2019). Agama, Ritual dan Konflik: Suatu Upaya Memahami Konflik Umat Beragama di Indonesia. Handep: Jurnal Sejarah Dan Budaya, 2(2), 123-142. https://doi.org/10.33652/handep.v2i2.41

Hariani, P. P., \& Wastuti, S. N. Y. (2020). Pemanfaatan E-Learning Pada Pembelajaran Jarak Jauh di Masa Pandemi Covid-19. Biblio Couns : Jurnal Kajian Konseling Dan Pendidikan, 3(1), 41-49. https://doi.org/10.30596/bibliocouns.v3i2.4656

Irmawati, E., Putri, N., Sari, I., Kusumahastuti, P. A., \& Surakarta, I. (2020). Analisis Kesalahan Berbahasa Bidang Morfologi Dan Ejaan Pada Judul Youtube Di Channel Baim Paula. Diglosia: Jurnal Pendidikan, Kebahasaan, Dan 
Kesusastraan

Indonesia,

4(2).

http://jurnal.unma.ac.id/index.php/dl/article/view/2124

Kementrian Pendidikan dan Kebudayaan Republik Indonesia, 1 (2020). https://drive.google.com/file/d/1VrAOA3Qz5bV2p6FgN7Xv7GHVmS0u44Er/vie w

Kemp, S. (2019). Digital 2019: Indonesia. Global Digital Insights, 17. https://datareportal.com/reports/digital-2020-indonesia

Kemp, S. (2020). Digital 2020 Report: Indonesia. In Global Digital Insights. https://datareportal.com/reports/digital-2020-indonesia

Kushendrawati, S. M. (2012). Multikultural Agama:Analisis Kritis Masalah Kerukukan Umat Beragama di Indonesia. Seminar Internasional Multikultural \& Globalisasi, 185.

Mahnun, N. (2012). Media Pembelajaran (Kajian terhadap Langkah-langkah Pemilihan Media dan Implementasinya dalam Pembelajaran). An-Nida', 37(1), 27-35.

Muslich, M. (2010a). Text Book Writing: Dasar-dasar Pemahaman, Penulisan, dan Pemakaian Buku Teks. Ar-Ruzz Media.

Muslich, M. (2010b). Textbook Writing: Dasar-dasar Pemahaman, Penulisan, dan Pemakaian Buku Teks. Ar-Ruzz Media.

Nur Latifah, Najib Hasan, Y. A. F. (2015). Pengembangan Media Pembelajaran Sparkol Videoscribe Terhadap Keterampilan Menulis Siswa Kelas Vi Sekolah Dasar Negri Sukamurni 1 Kabupaten Tengerang. Jurnal Madrasah Ibtidaiyah, 3(2), 116-127.

Sari, L. (2020). Upaya Menaikkan Kualitas Pendidikan Dengan Pemanfaatan Youtube Sebagai Media Ajar Pada Masa Pandemi Covid-19. Jurnal Tawadhu, 4(1), 10741084. https://ejournal.iaiig.ac.id/index.php/TWD/article/view/226

Sari, L. M. (2018). SIMBOL SALIB DALAM AGAMA KRISTEN. RELIGI JURNAL STUDI AGAMA-AGAMA, 14(2), 155. https://doi.org/10.14421/rejusta.2018.140201

Satrianingrum, A. P., \& Prasetyo, I. (2020). Persepsi Guru Dampak Pandemi Covid-19 terhadap Pelaksanaan Pembelajaran Daring di PAUD. Jurnal Obsesi : Jurnal Pendidikan Anak Usia Dini, 5(1), 633. https://doi.org/10.31004/obsesi.v5i1.574

Setiadi, E. F., Azmi, A., \& Indrawadi, J. (2019). Youtube Sebagai Sumber Belajar Generasi Milenial. Journal of Civic Education, 2(4), 313-323. https://doi.org/10.24036/jce.v2i4.135

Setiawan, T. Y., Arsil, A., \& Noviyanti, S. (2021). Pemanfaatan Youtube Pada Sistem Pembelajaran Dalam Jaringan Masa Pandemi Covid-19 Di Kelas Iic Sekolah Dasar.

Siahaan, M. (2020). Dampak Pandemi Covid-19 Terhadap Dunia Pendidikan. Jurnal Kajian Ilmiah, 1(1), 73-80. https://doi.org/10.31599/jki.v1i1.265

Sugiyono. (2012). Metode Penelitian Kuantitatif, Kualitatif dan R \& D.Bandung:Alfabeta. In Metode Penelitian Kuantitatif, Kualitatif dan $R \&$ D.Bandung:Alfabeta.

Suprapto, E., \& Suprapto, N. (2021). Analisis Kelayakan Video Pembelajaran Fisika Berbasis Platform Youtube Pada Materi Usaha Dan Energi. IPF: Inovasi Pendidikan Fisika, 10(1), 21-31.

Syah, R. H. (2020). Dampak Covid-19 pada Pendidikan di Indonesia: Sekolah, Keterampilan, dan Proses Pembelajaran. SALAM: Jurnal Sosial Dan Budaya SyarI, 7(5), 395-402. https://doi.org/10.15408/sjsbs.v7i5.15314

Warna - Wikipedia bahasa Indonesia, ensiklopedia bebas. (n.d.). Retrieved March 26, 
2021, from https://id.wikipedia.org/wiki/Warna

Widagdo, B. W., Handayani, M., \& Suharto, D. A. (2020). Dampak Pandemi Covid-19 Terhadap Perilaku Peserta Didik pada Proses Pembelajaran Daring Menggunakan Metode Pengukuran Skala Likert (Studi Kasus di Kabupaten Tangerang Selatan). Jurnal Teknologi Informasi ESIT, 63(2), 63-70. http://jurnaleresha.ac.id/index.php/esit/article/view/188

Winata, N. T. (2019). Analisis Kesalahan Ejaan Bahasa Indonesia Dalam Media Massa Daring (DETIKCOM). Bahtera Indonesia; Jurnal Penelitian Bahasa Dan Sastra Indonesia, 4(2), 115-121. https://doi.org/10.31943/bi.v4i2.52 